\title{
EKSISTENSI DAN TRANSFORMASI PETANI GUREM: KASUS PERTANIAN WILAYAH PINGGIRAN KOTA BANDUNG
}

\author{
Yonas Hangga Saputra \\ Pusat Sosial Ekonomi dan Kebijakan Pertanian (PSE-KP) \\ Jalan Ahmad Yani 70, Bogor 16161 \\ E-mail: yonas@pertanian.go.id
}

\begin{abstract}
This article aims at: (1) describing the existence and transformation of small-scale farmers; (2) identifying the problems of small-scale farmers related to the land tenure pattern, farming system, and institutional aspect; and (3) recommending the policy for small-scale farmers empowerment, case of sub-urban area of Bandung municipality. The research results show that the existence and transformation of small-scale farmers were degraded. The most problem faced by small-scale farmers in locale of the study was agricultural land conversion to non-agricultural purposes. Consequently, the proportion of small-scale farmers who operate their owned land was decreased and some of them transformed to the status of cultivated farmers either in rented or shared systems or became farm laborers. Moreover, the farm productivity was not optimal while the position of small-scale farmers especially the cultivated farmers became feeble in negotiation with owned land as well as in terms of capital aspect. The empowerment program intervention should be followed by technical assistance in line with aspiration of small-scale farmers toward collectively participatory in the organization of farmers. It should be implemented through participatory young generation both in on-farm and in off-farm activities.
\end{abstract}

Keywords: Existence, Transformation, Small-scale Farmer, sub-urban Area

\begin{abstract}
Abstrak: Artikel ini bertujuan: (1) mendeskripsikan eksistensi dan transformasi petani gurem; (2) mengidentifikasi permasalahan petani gurem terkait dengan pola penguasaan lahan, sistem usahatani, dan kelembagaan pertanian; dan (3) merekomendasikan kebijakan pemberdayaan petani gurem, kasus wilayah pinggiran Kota Bandung. Hasil penelitian menunjukkan bahwa eksistensi dan transformasi petani gurem mengalami degradasi. Permasalahan utama yang dihadapi petani gurem di lokasi penelitian adalah alih fungsi lahan pertanian ke non-pertanian. Konsekuensinya, proporsi petani gurem yang memiliki lahan pertanian semakin menurun dan sebagian beralih status menjadi petani penggarap (bagi hasil dan sewa) atau menjadi buruh tani. Berikutnya, produktivitas usahatani tidak optimal sedangkan posisi petani gurem terutama yang berstatus penggarap semakin lemah baik dalam bernegosiasi dengan pemilik lahan maupun dalam aspek permodalan. Intervensi program pemberdayaan seyogianya diiringi dengan bantuan teknis sesuai dengan aspirasi petani gurem agar dapat berpartisipasi secara kolektif melalui organisasi kelompok tani. Implementasinya juga harus melibatkan generasi muda agar termotivasi terjun ke bidang pertanian baik di dalam maupun di luar aktivitas usahatani.
\end{abstract}

Kata kunci: eksistensi, transformasi, petani gurem, wilayah pinggiran kota 
Yonas H. S. dan M. Iqbal : Eksistensi dan Transformasi Petani Gurem....

\section{PENDAHULUAN}

Undang-undang Nomor 13 tahun 2013 tentang Perlindungan dan Pemberdayaan Petani menjabarkan bahwa petani memiliki peran sentral dan memberikan kontribusi besar dalam penyelenggaraan pembangunan pertanian. Petani disebut sebagai pelaku utama pembangunan pertanian, tetapi hanya memiliki lahan pertanian dengan rataan di bawah 0,5 hektar per petani. Sebagian dari petani tidak memiliki lahan usahatani sendiri, atau disebut sebagai petani penggarap, bahkan juga buruh tani. Petani pada umumnya mempunyai posisi yang lemah dalam memperoleh sarana produksi, pembiayaan usahatani, dan akses pasar (Pemerintah RI, 2013).

Petani yang menguasai lahan kurang dari 0,5 hektar tergolong sebagai petani skala kecil, atau dikenal dengan istilah "petani gurem". Penguasaan lahan tersebut meliputi satu atau lebih kegiatan usaha tanaman padi, palawija, hortikultura, perkebunan, kehutanan, peternakan, budidaya ikan/biota lain di kolam air tawar/tambak air payau, dan penangkapan satwa liar (BPS Nasional, 2013).

Salah satu lokasi usahatani petani gurem terdapat di wilayah pinggiran kota. Lokasi tersebut dikenal dengan istilah "peri-urban agriculture" dimana menurut FAO (2001) didefinisikan sebagai: “.... farm units close to town that operate farms to grow plants, raise chickens and other livestock, as well as embrace other activities such as fish farming". Eksistensi dan transformasi petani gurem di wilayah pinggiran kota memiliki keunikan tersendiri, terutama terkait dengan fenomena alih fungsi lahan pertanian ke non-pertanian, dampak dari pembangunan wilayah perkotaan (urban development).

Petani merupakan salah satu sumber daya penting pendukung kelangsungan sektor pertanian. Oleh karena itu, pengembangan sumber daya manusia petani sebagai bagian dari komunitas pertanian (agricultural community development) merupakan elemen penting dalam menunjang pembangunan komoditas pertanian (agricultural commodity development).

Basis pengembangan sumber daya manusia petani adalah pemahaman terhadap eksistensi berikut transformasinya. Eksistensi sumber daya manusia petani perlu dipahami melalui kondisi terkini, sedangkan transformasinya patut dipelajari terkait dengan rentang perubahan antar waktu. Salah satu refleksi eksistensi dan transformasi sumber daya manusia petani dapat diamati dari Hasil Sensus Pertanian (ST).

Dengan memahami eksistensi dan transformasi petani, rancangan dan implementasi program pembangunan pemerintah (government intervention) termasuk bimbingan teknis (technical assistance) diharapkan tepat sasaran, termasuk petani gurem di wilayah pinggiran kota. Pemahaman tersebut juga bersinggungan langsung dengan aktivitas petani gurem itu sendiri, baik dari aspek pola penguasaan lahan dan sistem usahatani maupun aspek kelembagaannya.

Secara umum tujuan artikel ini adalah untuk menganalisis eksistensi dan transformasi petani gurem terkait dengan fenomena pertanian, kasus wilayah pinggiran Kota Bandung. Secara khusus artikel ini bertujuan: (1) mendeskripsikan eksistensi dan transformasi petani gurem; (2) mengidentifikasi permasalahan petani gurem terkait dengan pola penguasaan lahan, sistem usahatani, dan kelembagaan pertanian; dan (3) merekomendasikan kebijakan pemberdayaan petani gurem.

Pertanian skala kecil semakin menjadi perhatian terutama semenjak Perserikatan Bangsa Bangsa (PBB) mengakui keberadaan dan peran pentingnya dalam mengatasi krisis pangan dunia. Hal tersebut juga dikuatkan dalam pidato Direktur Jenderal FAO (Food and Agriculture Organization) pada acara Hari Pangan Sedunia (the World Food Day) tanggal 16 Oktober 2012 dengan topik "Small-Scale Farmers as A Key to Feeding the World" (FAO, 2012).

Di Indonesia, pada tanggal 9 Juli 2013, Rancangan Undang-Undang (RUU) Perlindungan dan Pemberdayaan Petani telah disahkan menjadi Undang-Undang (UU) Nomor 19 tahun 2013 (Pemerintah RI, 2013). Lahirnya UU tersebut disemangati oleh kesadaran bahwa selama ini petani relatif belum memperoleh perlindungan dan pemberdayaan sebagaimana mestinya, terutama petani skala kecil (gurem). Oleh karena itu, hakikat perlindungan dan pemberdayaan petani gurem paling tidak seyogianya ditempuh melalui tiga langkah strategi. Pertama, 
pemahaman terhadap eksistensi dan transformasi petani gurem. Kedua, pengetahuan tentang permasalahan yang dihadapi petani gurem. Ketiga, perencanaan terkait dengan intervensi perlindungan dan pemberdayaan petani gurem.

Bertitik tolak dari uraian diatas, kerangka pemikiran dalam artikel ini diilustrasikan pada Gambar 1. Intinya adalah berangkat dari pemahaman terhadap eksistensi dan transformasi serta permasalahan yang dihadapi petani gurem di wilayah pinggiran kota. Pemahaman terhadap eksistensi petani gurem diamati pada saat kondisi terkini (actual condition) sementara transformasinya ditelusuri melalui dinamika perubahan selama kurun waktu satu dasawarsa terakhir berdasarkan hasil Sensus Pertanian (ST 2003 dan ST 2013). Permasalahan yang paling menonjol dihadapi petani gurem adalah ancaman alih fungsi lahan pertanian ke non-pertanian yang sekaligus mempengaruhi aspek pola penguasaan lahan dan sistem usahatani serta aspek kelembagaan baik organisasi maupun aturan main di dalamnya. Berdasarkan pemahaman terhadap eksistensi dan transformasi berikut permasalahannya, program pemberdayaan dapat dirancang sesuai aspirasi dan partisipasi petani gurem dalam bentuk tindakan kolektif melalui wadah organisasi kelompok tani.

\section{METODE PENELITIAN}

Metode yang digunakan dalam penelitian ini adalah survei deskriptif (descriptive survey method). Survei dilaksanakan dalam bentuk pengamatan langsung terhadap fenomena dan fakta mengenai eksistensi dan transformasi serta permasalahan petani gurem di wilayah pinggiran kota (Kecamatan BojongsoangKabupaten Bandung).

\section{Data dan Informasi}

Data dan informasi berasal dari sumber primer dan sekunder. Data dan informasi primer diperoleh melalui wawancara dan diskusi kelompok terfokus (focus group discussion) dengan anggota kelompok tani, petugas, dan para pemangku kepentingan (stakeholders) yang relevan, serta pengamatan langsung di lapangan. Sementara itu, data dan informasi sekunder dikumpulkan dari dokumentasi laporan pada masing-masing intansi terkait.
Semua data data dan infromasi tersebut dianalisis secara deskriptif.

\section{Lokasi dan Jadwal Penelitian}

Lokasi penelitian dipilih secara sengaja (purposive), yaitu mewakili pertanian wilayah pinggiran kota. Pemilihan lokasi penelitian adalah berdasarkan telaahan dokumentasi data dan informasi sekunder berikut masukan dari nara sumber pada institusi terkait (Dinas Pertanian Kabupaten Bandung).

Lokasi penelitian berada di Kecamatan Bojongsoang (Kabupaten Bandung) yang berbatasan langsung dengan Kota Bandung. Dua desa terpilih di kecamatan tersebut masing-masing adalah Desa Tegalluar dan Desa Bojongsari. Setiap desa diwakili satu kelompok tani contoh, yaitu "Sugih Mukti" di Desa Tegalluar dan "Nurani Sejahtera" di Desa Bojongsari). Penelitian dilaksanakan pada bulan Desember 2014.

\section{HASIL DAN PEMBAHASAN}

\section{Eksistensi Petani Gurem}

Berdasarkan hasil Sensus Pertanian tahun 2013 (ST 2013), di Indonesia tercatat sebanyak 14.248.864 petani gurem, atau sekitar 55,33 persen dari 25.751.267 petani pengguna lahan pertanian nasional. Lebih dari dua pertiga bagian $(78,45 \%)$ petani gurem tersebut berada di pulau Jawa (BPS Nasional, 2013).

Khusus untuk Jawa Barat, tercatat sejumlah 2.298.193 petani gurem, atau sekitar 75,61 persen dari 3.039.716 petani pengguna lahan pertanian di provinsi ini (BPS Jabar, 2013). Secara proporsional, jumlah petani gurem Provinsi Jawa Barat menduduki posisi kelima di pulau Jawa (Gambar 2).

Dari 17 kabupaten dan 9 kota di Provinsi Jawa Barat, jumlah petani gurem tertinggi dan terendah masing-masing terdapat di Kabupaten Tasikmalaya (235.687 petani) dan di Kota Cirebon (1.995 petani). Akan tetapi, proporsi jumlah petani gurem terhadap jumlah petani pengguna lahan pertanian tertinggi dan terendah adalah di Kota Depok dan di Kabupaten Karawang, yaitu masing-masing 93,92 persen dan 53,06 persen (Gambar 3).

Khusus untuk Kabupaten Bandung, tercatat sebanyak 114.213 petani gurem, atau 88,11 persen dari 141.747 petani pengguna lahan 
pertanian setempat (BPS Bandung, 2013a). Proporsi jumlah petani gurem tertinggi dan terendah terdapat di Kecamatan Margahayu dan di Kecamatan Bojongsoang, yakni masingmasing 91,29 persen dan 62,61 persen (Gambar 4). Rendahnya proposi jumlah petani gurem terhadap jumlah petani pengguna lahan pertanian di Bojongsoang karena cukup tingginya transformasi penurunan jumlah petani gurem pada kecamatan yang bersangkutan, sehingga sebagian dari petani gurem tersebut berubah status menjadi petani penggarap atau beralih profesi menjadi pekerja di sektor non-pertanian.

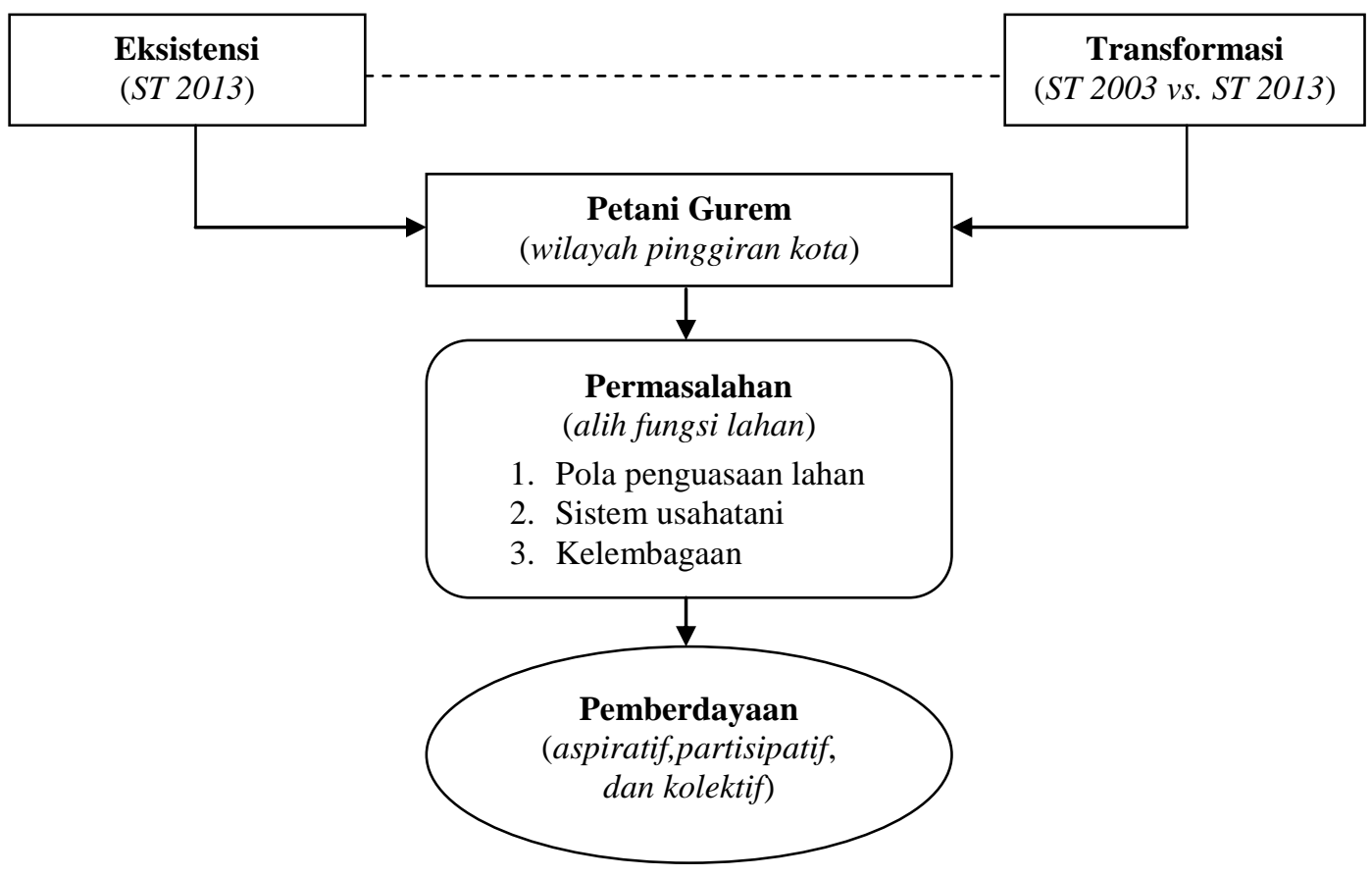

Gambar 1

Kerangka Pemikiran Eksistensi, Transformasi, dan Pemberdayaan Petani Gurem Wilayah Pinggiran Kota
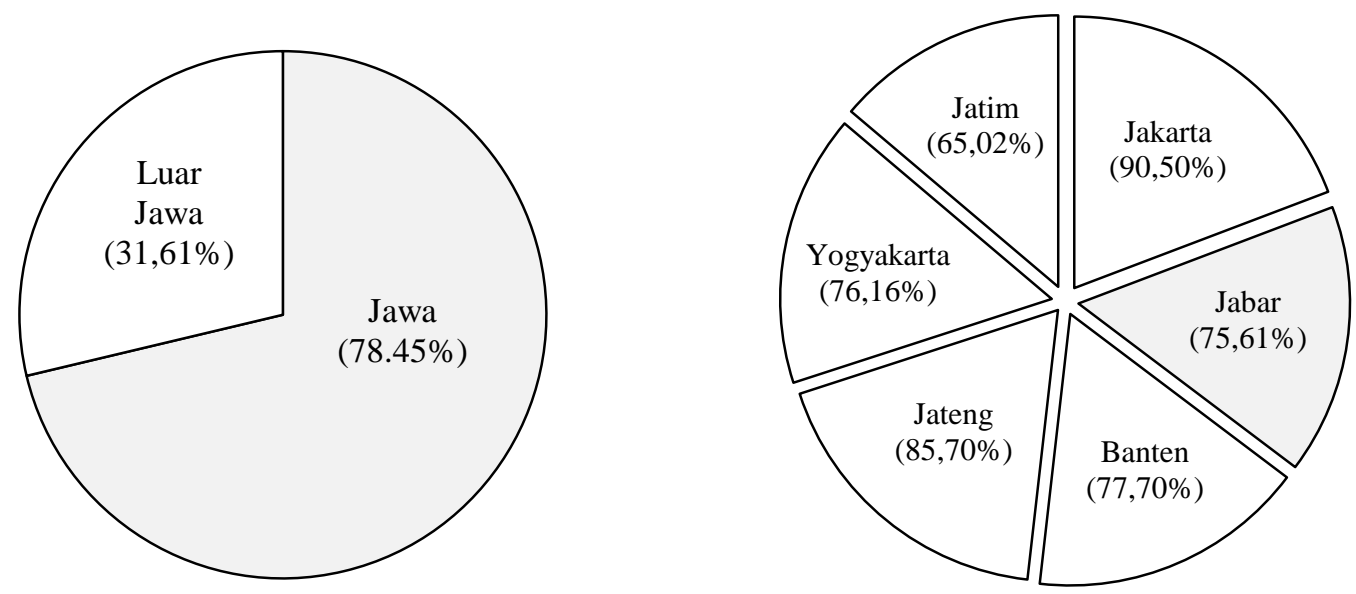

Gambar 2

Proporsi Jumlah Petani Gurem terhadap Jumlah Petani Pengguna Lahan Pertanian di Indonesia dan Jawa, 2013 (Sumber: BPS Nasional, 2013) 


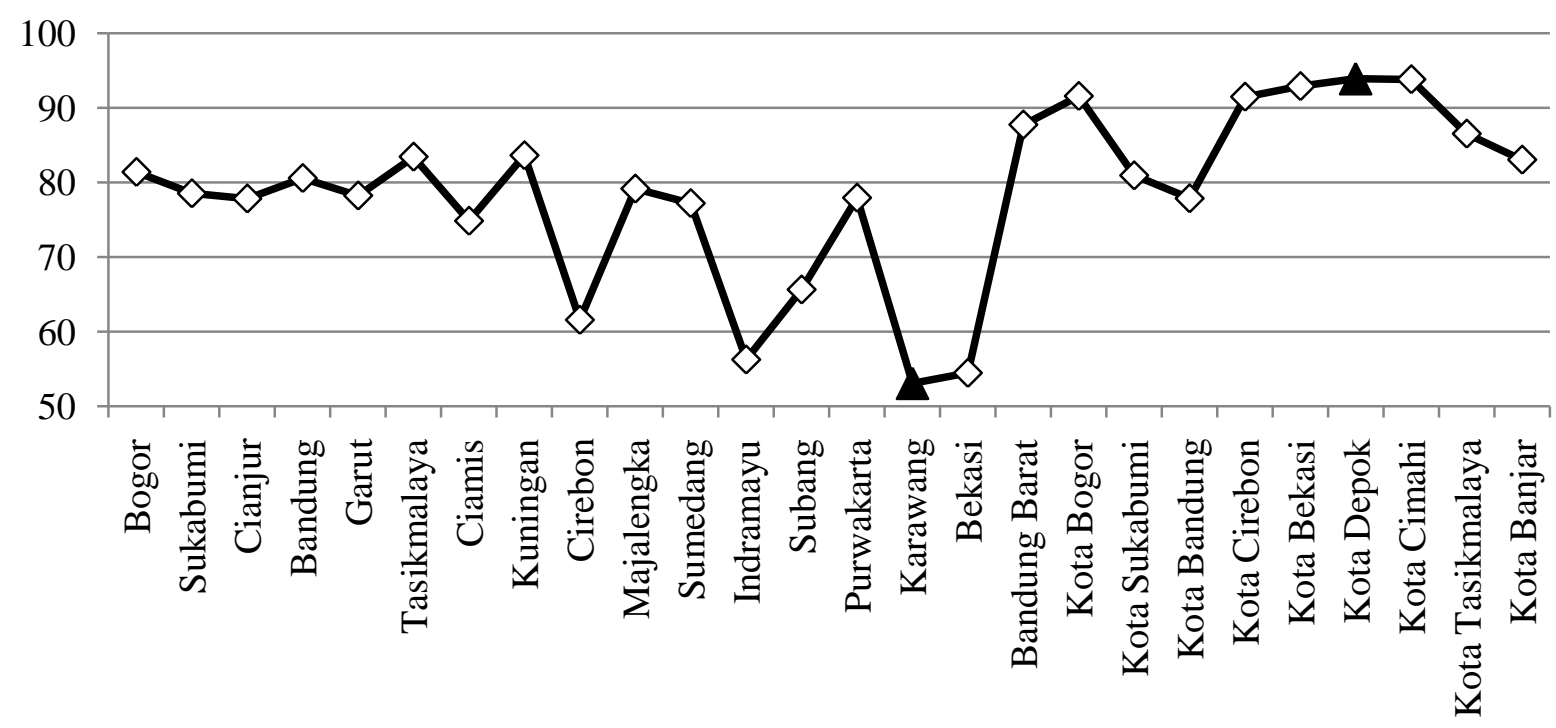

Gambar 3

Proporsi Jumlah Petani Gurem terhadap Jumlah Petani Pengguna Lahan Pertanian

Menurut Kabupaten dan Kota di Provinsi Jawa Barat, 2013 (\%)

(Sumber: BPS Jabar, 2013)

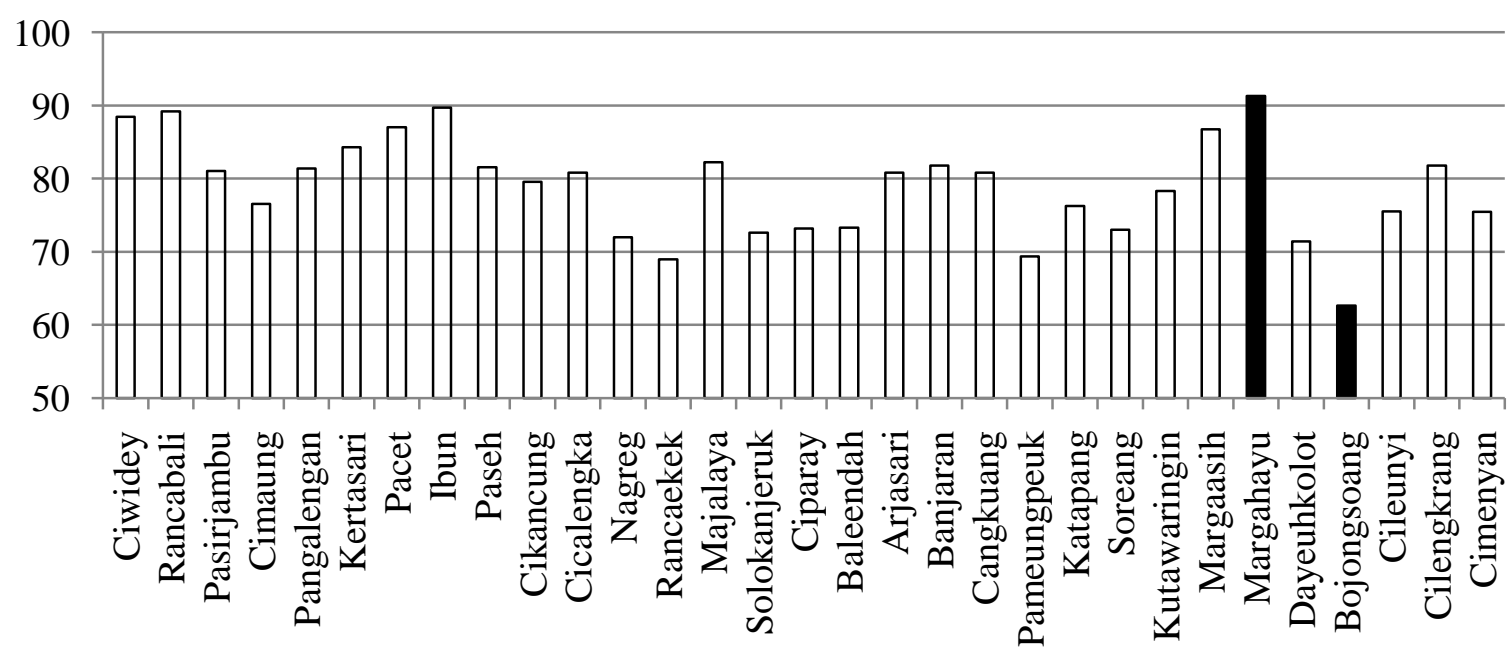

Gambar 4

Proporsi Jumlah Petani Gurem terhadap Jumlah Petani Pengguna

Lahan Pertanian Menurut Kecamatan di Kabupaten Bandung, 2013 (\%)

(Sumber: BPS Bandung, 2013a)

Tabel 1. Transformasi Jumlah Petani Gurem Indonesia, Provinsi Jawa Barat, Kabupaten Bandung, dan Kecamatan Bojongsoang, 2003-2013

\begin{tabular}{|c|c|c|c|c|c|}
\hline \multirow{2}{*}{ No. } & \multirow{2}{*}{ Uraian } & \multicolumn{2}{|c|}{ Jumlah } & \multicolumn{2}{|c|}{ Perubahan } \\
\hline & & 2003 & 2013 & Absolut & $\%$ \\
\hline 1. & Indonesia & 19.015 .051 & 14.248 .864 & -4.766 .187 & $-25,07$ \\
\hline 2. & Provinsi Jawa Barat & 3.501 .867 & 2.298 .193 & -1.203 .674 & $-34,37$ \\
\hline 3. & Kabupaten Bandung & 156.889 & 114.213 & -42.676 & $-27,20$ \\
\hline 4. & Kecamatan Bojongsoang & 2.242 & 819 & -1.423 & -63.47 \\
\hline
\end{tabular}

Sumber: BPS Nasional (2013), BPS Jabar (2013), dan BPS Bandung (2013a) 


\section{Transformasi Petani Gurem}

Selama kurun waktu satu dasawarsa terakhir (2003-2013), jumlah petani gurem di Indonesia mengalami transformasi penurunan cukup tinggi yaitu dari 19.015.051 petani (2003) menjadi 14.248.864 petani (2013). Dengan kata lain, selama kurun waktu tersebut terjadi transformasi penurunan absolut sekitar 4.766.187 petani gurem $(25,07 \%)$.

Transformasi penurunan jumlah petani gurem nasional merupakan resultante dari transformasi penurunan jumlah petani gurem baik regional (antar pulau), provinsi, kabupaten, maupun kecamatan. Pada Tabel 1 disajikan transformasi penurunan jumlah petani gurem mulai dari level nasional hingga level lokasi penelitian (Provinsi Jawa Barat, Kabupaten Bandung, dan Kecamatan Bojongsoang).

Dari Tabel 1 dapat diperhatikan bahwa lebih dari setengah $(63,47 \%)$ jumlah petani gurem di lokasi penelitian yaitu Kecamatan Bojongsoang mengalami transformasi penurunan selama kurun waktu satu dasawarsa terakhir (2003-2013). Terjadinya transformasi penurunan jumlah petani gurem yang cukup signifikan tersebut karena cukup maraknya alih fungsi lahan pertanian ke non-pertanian di kecamatan setempat. Sejumlah petani gurem yang sebelumnya memiliki lahan pertanian (2.242 petani) kemudian sebagian beralih menjadi petani tuna lahan (819 petani). Beberapa diantara petani tuna lahan tersebut berubah status menjadi petani penggarap, buruh tani, dan sebagian pindah profesi ke pekerjaan non-pertanian (terutama petani generasi muda).

Fenomena di atas muncul karena maraknya pembangunan di Kecamatan Bojongsoang sebagai salah satu wilayah penyangga pembangunan Kota Bandung. Dampak dari pembangunan tersebut adalah terjadinya alih fungsi lahan pertanian ke nonpertanian yang mempengaruhi baik langsung maupun tidak langsung terhadap pola penguasaan lahan, sistem usahatani, dan kelembagaan pertanian di lokasi setempat.

\section{Pola Penguasaan Lahan}

Fenomena penguasaan lahan di Kecamatan Bojongsoang (termasuk Desa Tegalluar dan Desa Bojongsari) merupakan representasi fenomena penguasaan lahan di Kabupaten Bandung. Fakta menunjukkan bahwa salah satu permasalahan terkait eksistensi lahan pertanian di kabupaten ini adalah terus berlangsungnya alih fungsi lahan pertanian ke non-pertanian. Sebagai catatan, data interpretasi citra SPOT (Systeme Probatoire d'Observation de la Terre) menunjukkan bahwa alih fungsi lahan pertanian ke non-pertanian yang terjadi di Kabupaten Bandung pada tahun 2004 hingga tahun 2011 adalah sekitar 1.898,34 hektar. Pada tahun 2011, lahan pertanian yang dilindungi RTRW (Rancangan Tata Ruang Wilayah) Kabupaten Bandung adalah seluas 18.498 hektar atau sekitar 50,78 persen dari total luas lahan pertanian setempat. Sisanya, yaitu sekitar 17.940 hektar $(49,25 \%)$ direncanakan untuk dialihfungsikan ke penggunaan non-pertanian. Konsekuensinya, eksistensi lahan pertanian menjadi semakin menyempit (Kecamatan Bojongsoang, 2012).

Paling tidak ada dua faktor penyebab terjadinya penyempitan lahan pertanian di lokasi penelitian. Pertama, adanya fragmentasi atau penyusutan kepemilikan lahan pertanian karena pola pewarisan. Akibatnya, sebagian dari lahan tersebut dijual oleh ahli waris karena dianggap tidak mencukupi untuk diusahakan secara optimal. Hasil penjualannya direncanakan untuk modal usaha di luar sektor pertanian. Akan tetapi hanya beberapa petani yang beruntung dari hasil penjualan lahan tersebut, sehingga akhirnya sebagian menjadi petani penggarap atau buruh tani di lahannya sendiri. Kedua, alih fungsi lahan melalui transaksi penjualan kepada perorangan atau pengusaha dari luar desa yang notabene kurang mengerti atau tidak menghiraukan eksistensi lahan pertanian di lokasi setempat. Biasanya, sebelum dialihfungsikan ke penggunaan nonpertanian, lahan pertanian tersebut boleh diusahakan oleh petani penggarap sampai batas waktu yang tidak ditentukan. Namun para petani penggarap diliputi rasa kekhawatiran mengingat alih fungsi penggunaan lahan yang dimaksud sewaktu-waktu bisa terjadi dan dapat mengakibatkan mereka kehilangan pekerjaan.

Fenomena jual beli lahan boleh dikatakan cukup marak di lokasi penelitian. Hal tersebut disebabkan oleh beberapa hal, diantaranya: (1) secara geografis lokasinya berada di bagian wilayah cekungan Daerah Aliran Sungai (DAS) Citarum yang sering mengalami kebanjiran, terutama pada saat musim hujan; dan (2) secara administratif 
letaknya berbatasan dengan Kota Bandung dengan geliat pembangunan cukup gencar, khususnya untuk industri dan pemukiman.

Fenomena alih fungsi lahan pada lokasi penelitian menunjukkan bahwa frekuensinya lebih tinggi di Desa Tegalluar dari pada di Desa Bojongsari. Dengan kata lain, Desa Tegalluar boleh dikatakan lebih rentan terhadap alih fungsi lahan pertanian ke penggunaan nonpertanian dibandingkan dengan Desa Bojongsari. Hal tersebut karena lokasi Desa Tegalluar relatif lebih dekat ke Kota Bandung dibandingkan dengan Desa Bojongsari. Sekitar 70 persen lahan sawah di Desa Tegalluar telah beralih fungsi dan umumnya jatuh ke tangan orang dari luar desa. Sebagian dari lahan yang dimaksud digarap oleh petani setempat dan sebagian lagi diusahakan petani dari luar desa secara temporer, karena sewaktu-waktu dapat beralih fungsi ke penggunaan non-pertanian.

Fenomena eksistensi lahan sebagaimana dikemukakan di atas menimbulkan dampak pada pola penguasaan lahan di lokasi penelitian. Selain pola penguasaan milik yang semakin terbatas skalanya, pola penguasaan lainnya adalah berupa bagi hasil, sewa, dan bayar PBB (Pajak Bumi dan Bangunan), dan gadai dengan uraian sebagai berikut:

1. Terdapat tiga pola bagi hasil. Pertama, bagi hasil setengah (50\% vs 50\%) dimana biaya penggarapan ditanggung penggarap sedangkan bibit dan pupuk dibiayai oleh pemilik. Kedua, bagi hasil separoh $(50 \%$ vs. 50\%) setelah dipotong biaya yang sebelumnya ditanggung pemilik berdasarkan konversi hasil panen. Ketiga, bagi hasil sepertiga dimana penggarap mendapatkan bagian 66,67 persen dan pemilik memperoleh bagian 33,33 persen dengan ketentuan seluruh biaya ditanggung penggarap.

2. Bayar PBB, dimana pola ini paling banyak diminati dan jadi rebutan karena dengan membayarkan PBB sekitar Rp 1,6 juta per hektar per tahun, penggarap dapat menikmati seluruh hasil panen garapannya.

3. Ada dua pola sewa lahan yang cukup menonjol. Pertama, sewa lahan senilai tiga kilogram per tumbak (2,1 ton/hektar). Pola sewa lahan seperti ini lebih banyak dilakukan dimana penggarap membayarkan sebagian sewanya (uang muka) di awal (sebelum digarap) dengan perhitungan harga gabah hasil panen musim tanam sebelumnya. Kedua, sewa lahan Rp 5.000 per tumbak (Rp 3,5 juta/hektar) per musim tanam. Pola ini berlaku pada budidaya tanaman ketimun (45 hari / musim tanam) dimana penyewanya berasal dari luar desa (misalnya Baleendah).

Dari uraian di atas secara umum dapat dikemukakan bahwa fenomena "guremisasi" cukup gencar terjadi di lokasi penelitian. Dengan kata lain, skala pemilikan lahan petani menjadi semakin sempit atau bahkan ada petani yang tidak memiliki lahan lagi (tuna lahan). Fenomena tersebut berlangsung seiring perjalanan waktu dan menimbulkan dampak sosial.

Ungkapan keprihatinan petani gurem di Kecamatan Bojongsoang adalah "Hirup ripuh, batin nyeri" (hidup susah, batin sakit). Menyadari hal tersebut, petani setempat hanya dapat berikhtiar dan berusaha sesuai kondisi yang ada. Fenomena tersebut umumnya dijewantahkan kepada anak agar tidak mengikuti jejak orang tuanya sebagai "petani”. Konsekuensinya, minat generasi muda menjadi menurun atau enggan terjun dalam pekerjaan pertanian. Situasi demikian diperparah lagi dengan pola pewarisan lahan pertanian yang menjadikan skalanya makin menyempit sehingga tidak dapat diandalkan sebagai sumber mata pencaharian pokok keluarga.

\section{Sistem Usahatani}

Jenis usahatani utama di lokasi penelitian adalah padi yang ditanam dua kali setahun, yaitu: (1) musim hujan (MH) yang berlangsung dari bulan Januari hingga bulan April/Mei; dan (2) musim kemarau pertama (MK I) dari bulan Juni/Juli sampai dengan bulan Oktober. Pada musim kemarau kedua (MK II), lahan pertanian cenderung tidak ditanami (bera) dan sebagian ditanami tanaman sayuran (ketimun). Pola tanam pada lahan sawah di Desa Tegalluar adalah padi-padi-bera, sedangkan pola tanam di Desa Bojongsari yaitu padi-padi-ketimun. Jenis padi yang umum digunakan adalah varietas Ciherang. Beberapa orang petani pernah mengusahakan tanaman jagung tetapi kurang berhasil. 
Sumber pengairan lahan sawah berasal dari irigasi dan pompa air. Keberadaan pompa air sangat diperlukan, khususnya selama musim kemarau. Nilai sewa pompa air milik perorangan dan kelompok masing-masing sekitar 700 kilogram per hektar per musim tanam dan 670 kilogram per hektar per musim tanam.

Ketersediaan traktor baik milik pribadi maupun punya kelompok relatif cukup. Nilai sewa traktor masing-masing untuk milik pribadi dan punya kelompok adalah $\mathrm{Rp}$ 1.400.000 per hektar dan Rp 1.200.000 per hektar. Nilai sewa tersebut dibagi antara operator $(40 \%)$ dan pemilik traktor $(60 \%)$. Biaya bahan bakar (solar) serta makan, rokok, bir (penghangat badan) operator, dan lain-lain ditanggung pemilik traktor.

Upah tanam padi masing-masing $\mathrm{Rp}$ 30.000 hingga $\mathrm{R} 35.000$ per orang per hari (tenaga kerja luar Bojongsoang) dan Rp 40.000 per orang per hari (tenaga kerja setempat). Tenaga kerja dari luar dijemput dan diantar oleh pemilik (pengguna tenaga kerja). Sebagai catatan, tenaga kerja setempat diambil oleh petani kaya karena pekerjaannya lumintu (terus menerus) pada lahan yang cukup luas. Sebaliknya, petani yang memiliki lahan sempit kesulitan mencari tenaga kerja upahan lokal setempat. Sementara itu, penggunaan pupuk boleh dikatakan cukup tinggi karena petani menganggap lahannya kurang subur. Sementara itu, upah tenaga kerja cukup mahal, masingmasing untuk laki-laki (Rp 50.000/orang/hari) dan perempuan ( $R p$ 40.000/orang/hari) selama lima jam kerja per hari.

Selain mengalami krisis lahan, lokasi penelitian juga menghadapi krisis tenaga kerja. Petani yang mau terjun ke sawah adalah yang berusia di atas 50 tahun. Bagi yang berusia di bawah 50 tahun bekerja di bangunan, pabrik, dan jenis pekerjaan lain di kota. Kekurangan tenaga kerja didatangkan dari luar desa seperti Ciparay dan Selokan Jeruk. Dulu tenaga kerja yang cari panen, tetapi sekarang pemilik yang cari tenaga kerja panen. Dulu perhitungan upah panen adalah sekitar 10 kilogram per kwintal, tetapi sekarang naik menjadi 20 kilogram per kwintal ditambah biaya angkut.

Rataan produktivitas padi $\mathrm{MH}$ adalah sekitar 8 kwintal per 100 tumbak $(5,6$ ton/hektar), sedangkan padi MK sekitar 6 kwintal per 100 tumbak (4,2 ton/hektar). Secara hitungan kasar, 100 tumbak (0,14 hektar) lahan sawah menghasilkan sekitar 8 kwintal GKP. Dengan harga Rp 3.750 per kilogram, diperoleh penerimaan sekitar $\mathrm{Rp}$ 3.000.000. Setelah dipotong biaya produksi sekitar Rp 2.000.000, maka pendapatan hanya Rp 1.000.000. Dengan kata lain, petani hanya memperoleh keuntungan sekitar 30 persen dari hasil produksi. Melalui bagi hasil, nilai keuntungan tersebut akan semakin berkurang lagi (tergantung polanya). Perhitungan tersebut merupakan fakta umum mengingat rataan luas penguasaan lahan sawah cukup sempit (bukan dalam skala hektaran).

Harga jual gabah kering panen (GKP) adalah sekitar Rp 3,700-3,800 per kilogram pada saat panen. Padahal kalau petani mau menunggu, harganya bisa mencapai Rp 4,000 per kilogram. Namun petani keburu harus menjual karena desakan kebutuhan keluarga disamping adanya kendala ketersediaan fasilitas penyimpanan. Bertitik tolak dari kendala tersebut sebagian petani menjual hasil panen padinya secara "tebasan", terutama pada musim hujan. Nilai tebasan berkisar antara Rp 5.000 per tumbak hingga $\mathrm{Rp} 6.000$ per tumbak (Rp 3,5-4,2 juta per hektar). Perbandingan proporsi antara panen tebasan dengan panen bukan tebasan antar musim tanam masingmasing pada musim hujan (50\% vs. $50 \%)$ dan pada musim kemarau (60\% vs. $40 \%)$. Sebagai catatan, sebagian besar $(90 \%)$ hasil panen padi dijual dan sisanya (10\%) untuk pemenuhan konsumsi rumah tangga.

Lokasi penelitian memiliki keterbatasan fasilitas lantai jemur karena sempitnya ketersediaan lahan. Kondisi tersebut mendorong petani untuk segera menjual GKP disamping karena tuntutan kebutuhan uang. Satu-satunya fasilitas lantai jemur yang cukup memadai hanya tersedia di kecamatan dengan kapasitas penjemuran sekitar 4,5 ton gabah.

\section{Kelembagaan Pertanian}

Paling tidak ada tiga aspek kelembagaan yang mewarnai eksistensi petani gurem di lokasi penelitian. Ketiga aspek tersebut masingmasing terkait dengan: (1) penguasaan lahan; (2) permodalan; dan (3) organisasi kelompok tani.

\section{Penguasaan Lahan}

Sebagaimana telah diuraikan sebelumnya, pola penguasaan lahan di lokasi penelitian terdiri 
dari milik, sewa, bagi hasil, dan bayar PBB. Pola penguasaan lahan di Desa Tegalluar lebih bervariasi dibandingkan dengan pola penguasaan lahan di Desa Bojongsari (Tabel 2).

Dari Tabel 2 dapat diperhatikan bahwa proporsi pola penguasaan lahan milik sangat kecil, khususnya di Desa Tegalluar. Terdapat beberapa fenomena terkait dengan penguasaan lahan pertanian di lokasi penelitian, yaitu:

1. Penentuan pola penguasaan lahan tergantung pada kesepakatan awal antara pemilik dengan penggarap. Biasanya penerapan pola penguasaan lahan tersebut dilakukan sejak transaksi jual beli.

2. Tidak semua pemilik lahan menguasakan lahan kepada penggarap dengan pola yang sama. Umumnya pemilik lahan menguasakan lahannya untuk digarap secara temporer oleh petani penggarap, namun dalam batas waktu yang tidak ditentukan. Dengan kata lain, kapanpun (lahan tersebutdapat digunakan oleh pemilik. Konsekuensinya, petani yang menggarap lahan tersebut harus menyerahkan sepenuhnya kepada pemilik (tanpa syarat). Biasanya setelah tidak digarap, lahan pertanian yang dimaksud dialihfungsikan ke lahan non-pertanian (pabrik atau gudang).

3. Penyerahan penguasaan lahan dari pemilik kepada petani penggarap dapat menyebabkan pengelolaannya menjadi tidak optimal. Bahkan pada beberapa kasus terjadi pengalihan wewenang pengelolaan lahan ke petani penggarap berikutnya. Dalam hal ini petani penggarap pertama berperan jadi manajer atau hanya sebagai perantara saja. Keberadaan petani penggarap sifatnya musiman (ganti-ganti) sehingga relatif sulit diarahkan untuk kegiatan suatu program.

4. Pengaruh pemilik cukup tinggi dalam pengelolaan lahan, bahkan lebih menentukan dibandingkan peran penggarap lahan. Misalnya, apabila penggarap lahan mau menerapkan anjuran teknologi baru, pemilik lahan memiliki kekhawatiran terhadap kegagalan (penurunan produksi) yang berimplikasi pada berkurangnya bagi hasil atau pendapatan yang diperoleh. Jika tidak mengikuti kehendak pemilik lahan, dampaknya dapat berupa pemutusan hubungan kerjasama. Oleh karena itu, peran pemilik lahan cukup menentukan dalam penerapan teknologi dan peningkatan produktivitas lahan.

\section{Permodalan}

Selain permasalahan sempitnya lahan karena dampak dari alih fungsi dan fragmentasi lahan, permasalahan krusial lainnya yang dihadapi petani di lokasi penelitian adalah modal usahatani. Sebagian besar petani (khususnya penggarap) memperoleh fasilitas modal dari pemilik lahan dan pedagang (tengkulak). Besarnya modal dari masing-masing sumber tersebut bervariasi, yaitu tergantung kesepakatan antar penyedia dan peminjam modal. Dengan kata lain, tidak ada ketentuan formal yang mengatur kesepakatan tersebut, namun posisi petani berada di pihak yang lemah.

Alternatif lain, misalnya melalui lembaga keuangan formal, kurang/tidak terjangkau oleh petani. Pengajuan pinjaman oleh petani (kelompok tani) boleh dikatakan tidak mendapat respon dari lembaga perbankan. Penyebabnya karena posisi petani lemah dari sisi agunan yang menjadi persyaratan mutlak bagi bank. Bukti temuan sederhana (anecdotal evidence) menujukkan bahwa realisasi kredit sepeda motor lebih mudah dibandingkan realisasi kredit usahatani. Hal tersebut karena kredit sepeda motor dapat dicicil bulanan sementara kredit usahatani tidak dapat dicicil musiman (per musim tanam).

\section{Organisasi Kelompok Tani}

Menurut UU No. 19/2013 tentang Perlindungan dan Pemberdayaan Petani, kelompok tani didefinisikan sebagai: “.... kumpulan petani/peternak/pekebun yang dibentuk atas dasar kesamaan kepentingan; kesamaan kondisi lingkungan sosial, ekonomi, sumber daya; kesamaan komoditas; dan keakraban untuk meningkatkan serta mengembangkan usaha anggota". Dengan demikian dapat digarisbawahi bahwa kelompok tani merupakan kumpulan (organisasi) dengan tujuan untuk meningkatkan serta mengembangkan usaha anggota. Implementasi kegiatan peningkatan 
dan pengembangan petani sejatinya ditempuh melalui media kelompok tani karena sifatnya kolektif (bukan individu).

Karakteristik kelompok tani contoh di lokasi penelitian disajikan pada Tabel 3. Perlu dikemukakan bahwa basis pembentukan kelompok tani tersebut adalah berdasarkan hamparan. Rataan usia anggota kelompok tani tergolong kategori tua ( $>50$ tahun) dengan pendidikan dominan Sekolah Dasar (SD). Sementara itu, secara agregat proporsi petani penggarap lebih tinggi dibandingkan proporsi petani pemilik.

Dari Tabel 3 dapat digarisbawahi bahwa pengembangan kelompok tani harus disesuaikan dengan usia anggotanya yang relatif sudah tua, sebagian besar berpendidikan $\mathrm{SD}$, dan tingginya proporsi petani dengan status sebagai penggarap. Eksistensi anggota kelompok yang berstatus sebagai petani penggarap patut dijadikan perhatian terutama apabila dikaitkan dengan penerapan dan keberlanjutan inovasi teknologi. Sebagaimana telah diuraikan sebelumnya bahwa adopsi inovasi teknologi lebih ditentukan oleh pemilik lahan, sementara petani penggarap cenderung menggarap lahan pertanian secara berganti- ganti. Satu fenomena yang cukup menggelitik (surprise) ditemukan yaitu terkait dengan Kartu Tanda Penduduk (KTP). Banyak KTP anggota kelompok tani yang identitas pekerjaannya bukan sebagai petani, tetapi malahan sebagai wiraswasta atau buruh harian lepas. Sekalipun fenomena tersebut cukup sepele, namun perlu dijadikan perhatian baik dari sisi ketertiban administrasi kependudukan maupun dalam hal kelancaran mekanisme penyaluran bantuan.

\section{KESIMPULAN DAN SARAN}

\section{Kesimpulan}

Proporsi jumlah petani gurem baik tingkat Nasional, Provinsi Jawa Barat, Kabupaten Bandung, maupun Kecamatan Bojongsoang cukup tinggi, yaitu masing-masing sekitar 55,33 persen, 75,61 persen, 80,58 persen, dan 62,61 persen dari jumlah petani pengguna lahan pertanian pada setiap tingkat tersebut. Selama kurun waktu satu dasawarsa terakhir, proporsi jumlah petani gurem mengalami transformasi penurunan masing-masing sekitar 25,07 persen (Indonesia), 34,37 persen (Provinsi Jawa Barat), 27,20 persen (Kabupaten Bandung), dan 63,47 persen (Kecamatan Bojongsoang).

Tabel 2. Pola Penguasaan Lahan di Lokasi Penelitian, 2014 (\%)

\begin{tabular}{clcc}
\hline No. & \multicolumn{1}{c}{ Pola Penguasaan Lahan } & Tegalluar & Bojongsari \\
\hline 1. & Milik & 13,04 & 52,17 \\
2. & Bagi hasil & 21,74 & 47,83 \\
3. & Sewa & 34,78 & 0 \\
4. & Bayar PBB & 30,43 & 0 \\
\hline \multicolumn{2}{r}{ Total } & 100,00 & 100,00 \\
\hline
\end{tabular}

Sumber: Kelompok Tani Sugih Mukti dan Nurani Sejahtera (2014)

Tabel 3. Karakteristik Kelompok Tani Contoh di Lokasi Penelitian, 2014

\begin{tabular}{|c|c|c|c|}
\hline \multirow{2}{*}{ No. } & \multirow{2}{*}{ Karakteristik } & \multicolumn{2}{|c|}{ Kelompok Tani } \\
\hline & & Sugih Mukti & Nurani Sejahtera \\
\hline 1. & Jumlah anggota (jiwa) & 23 & 20 \\
\hline \multirow[t]{4}{*}{2.} & Usia anggota (tahun): & & \\
\hline & a. Tertua & 75 & 68 \\
\hline & Termuda & 38 & 42 \\
\hline & c. Rata-rata & 56 & 53 \\
\hline \multirow[t]{5}{*}{3.} & Pendidikan anggota $(\%)$ : & & \\
\hline & a. $\mathrm{SD}$ & 60,87 & 65,00 \\
\hline & SLTP & 21,74 & 15,00 \\
\hline & SLTA & 13,04 & 15,00 \\
\hline & d. Perguruan Tinggi & 4,35 & 5,00 \\
\hline \multirow[t]{3}{*}{4.} & Status anggota $(\%)$ : & & \\
\hline & a. Petani pemilik & 13,04 & 52,57 \\
\hline & Petani penggarap & 86,96 & 47,83 \\
\hline
\end{tabular}

Sumber: Kelompok Tani Sugih Mukti dan Nurani Sejahtera (2014) 
Yonas H. S. dan M. Iqbal : Eksistensi dan Transformasi Petani Gurem....

Tingginya transformasi penurunan jumlah petani gurem, khususnya di Kecamatan Bojongsoang (lokasi penelitian), karena cukup gencarnya alih fungsi lahan pertanian ke nonpertanian dampak dari pembangunan wilayah pinggiran Kota Bandung. Konsekuensinya, sebagian besar petani gurem berubah status menjadi petani penggarap baik melalui pola bagi hasil maupun sewa atau menjadi buruh tani. Proporsi petani gurem yang berstatus sebagai penggarap masing-masing 86,96 persen di Desa Tegalluar dan 47,83 persen di Desa Bojongsari. Desa Tegalluar boleh dikatakan lebih rentan terhadap alih fungsi lahan pertanian ke penggunaan non-pertanian dibandingkan dengan Desa Bojongsari. Hal tersebut karena lokasi Desa Tegalluar relatif lebih dekat ke Kota Bandung dibandingkan dengan Desa Bojongsari. Dampak berikutnya adalah produktivitas usahatani tidak dapat diperoleh secara optimal. Sementara itu, generasi muda di kedua desa penelitian cenderung enggan terjun ke sektor pertanian dan lebih memilih bekerja di bidang nonpertanian.

Posisi petani gurem, khususnya penggarap, cukup lemah baik dalam bernegosiasi dengan pemilik lahan maupun terkait dengan aspek permodalan. Pemilik lahan cukup berperan dalam penerapan inovasi teknologi pertanian. Dengan kata lain, apabila petani penggarap mau menerapkan inovasi teknologi pertanian tetapi pemilik lahan merasa enggan menerapkannya, maka inovasi teknologi tersebut gagal diimplementasikan. Dari kelompok tani yang diteliti, secara agregat proporsi pemilik lahan masing-masing 86,96 persen pada kelompok tani "Sugih Mukti" di Desa Tegalluar dan 52,17 persen pada kelompok tani "Nurani Sejahtera" di Desa Bojongsari.

\section{Saran}

Eksistensi dan transformasi serta permasalahan yang dialami petani gurem, khususnya di lokasi penelitian, memerlukan perhatian serius untuk diatasi terutama terkait dengan aspek pemberdayaan (empowerment). Implementasinya tidak hanya melalui bantuan kegiatan (intervention program) semata melainkan juga harus diiringi dengan pendampingan atau bimbingan teknis (technical assistance). Basisnya adalah sesuai dengan apirasi petani gurem untuk terlibat secara partisipatif melalui tindakan kolektif (collective action) dalam organisasi kelompok tani seraya menjaga keberlanjutannya (sustainability) dengan melibatkan generasi muda pertanian.

Mengingat luas lahan pertanian semakin mengecil (guremisasi), maka pilihan program pemberdayaan petani gurem harus dilakukan secara selektif. Fokusnya adalah kegiatan baik di dalam usahatani (on-farm) maupun di luar usahatani (off-farm) yang berorientasi agribisnis. Untuk kegiatan di dalam usahatani (on-farm) patut dipertimbangkan introduksi usahatani hortikultura khususnya sayuran untuk dipasok ke Kota Bandung. Sekalipun kota ini berada di sekitar sentra produksi hortikultura, diharapkan pilihan introduksi jenis tanaman sayurannya adalah yang memiliki daya saing cukup tinggi. Selain itu, jenis tanaman hidroponik atau semi-hidroponik dengan teknologi hemat lahan yang dikombinasikan dengan penerapan pertanian organik juga patut dipertimbangkan untuk diintroduksikan kepada petani gurem. Sementara itu, untuk kegiatan di luar usahatani (off-farm), diperlukan introduksi teknologi dimana salah satunya terkait dengan perbengkelan misalnya Unit Pelayanan Jasa Alat dan Mesin Pertanian (UPJA). Introduksi teknologi tersebut diharapkan dapat menarik generasi muda dengan catatan agar kegiatannya dilaksanakan secara profesional.

Pemilik lahan juga perlu dirangkul agar mau terlibat dalam program pemberdayaan petani gurem setempat. Terkait dengan itu, penertiban administrasi kepemilikan lahan pertanian perlu ditata secara baik, kontinyu, dan senantiasa diperbarui (updated). Hal tersebut cukup penting agar data kepemilikan lahan baik luas dan nama pemilik maupun status kekiniannya dapat terlacak sewaktuwaktu. Wujudnya dapat ditempuh misalnya dengan menerbitkan dan sekaligus mengimplementasikan Peraturan Desa (Perdes). Hal lainnya, dalam setiap pengadaan program kegiatan dan bimbingan teknis patut dipertimbangkan pemberian kartu identitas petani penerima manfaat (program benficiaries) agar implementasinya tepat sasaran. 
Yonas H. S. dan M. Iqbal : Eksistensi dan Transformasi Petani Gurem....

\section{DAFTAR PUSTAKA}

BPS Bandung. 2013a. Hasil Sensus Pertanian 2013 Kabupaten Bandung. Badan Pusat Statistik Kabupaten Bandung. Soreang.

BPS Bandung. 2013b. Kecamatan Bojongsoang Dalam Angka 2013. Badan Pusat Statistik Kabupaten Bandung. Soreang.

BPS Nasional. 2013. Hasil Sensus Pertanian 2013 (Angka Tetap). Berita Resmi Statistik Nomor 90/12/Th. XVI, 2 Desember 2013. Badan Pusat Statistik. Jakarta.

BPS Jabar. 2013. Hasil Sensus Pertanian 2013 Provinsi Jawa Barat. Badan Pusat Statistik Provinsi Jawa Barat. Bandung.

FAO. 2001. Urban and Peri-Urban Agriculture: Special Programme for Food Security (SPFS). Food and Agriculture
Organization of the United Nations. Rome. Italy.

FAO. 2012. Small-Scale Farmers as A Key to Feeding the World. Food and Agriculture Organization of the United Nations. Rome.<permaculturenews.org/.../unsmall-farmer> (Desember 2014).

IFAD. 2013. New Directions for Smallholder Agriculture (edited by P. Hasell and A. Rahman). International Fund for Agricultural Development. Oxford Press. Oxford, United Kingdom.

Kecamatan Bojongsoang. 2012. Laporan Akuntabilitas Kinerja Instansi Pemerintah Kecamatan Bojongsoang. Bojongsoang.

Pemerintah RI. 2013. Undang Undang Nomor 19 tahun 2013 tentang Perlindungan dan Pemberdayaan Petani. Pemerintah Republik Indonesia. Jakarta. 